\title{
The Role of Muslim in Developing of Islamic Economy in Indonesia
}

\author{
Muhammad Sholahuddin \\ Faculty of Economics \& Business \\ Universitas Muhammadiyah Surakarta \\ Surakarta, Central Java, Indonesia \\ e-mail: muhammad.sholahuddin@ums.ac.id
}

\begin{abstract}
This paper critisizes Weber's thesis. His thesis has been used to understand the relationship between behavior and economic development and spiritual awareness among the socialeconomic structure and doctrine believed. This paper also compares development planning in Indonesia which proposed by various parties, e.g. political parties, mass organizations, NGOs, and other community components. The concept of Islamic economics can be viewed as an alternative solution to deal with the weakness of the idea of Western ideas of liberal globalization and modernization. So that, this paper also discusses role of moslem in Indonesia for development. To analysis three aims, the author uses literature study. It can be found that In testing the validity of Weber's thesis, Alatas ensure that the Weber thesis suggests a causal relationship-one symptoms cause other symptoms-not just looking for a mutual affinity. Discussion on the best model of development in Indonesia is still in progress among the scholars, scientist, political party and mass organizations. There are three school of thought in term of development concept. First, the concept of development that is based on classical and neoclassical economists. Second, the concept of development based on fully Islamic system. Third, both with adjustable compromising situations and conditions in Indonesia.
\end{abstract}

\section{Keywords-Weber's thesis, Islamic Economics, Development}

\section{INTRODUCTION}

Indonesia is a big country with a territory totalling an approximate 5 million $\mathrm{km}^{2}$. That country has a population of 240 million people with a Muslim population of $87 \%$. The Indonesian population is equivalent to the entire population of the European Union. Indonesia's natural wealth is abundant (1). According to the McKinsey Global Institute, Indonesia is currently ranked the fifth most important economy in Asian countries behind China, Japan, India, and South Korea. It is an established member of the G-20 (2). Indonesia's economy has a bright future. The Indonesian economy is currently the 16th largest in the world and with its abundant natural resources and untapped potential it is set to become the seventh largest economy in the year 2030.

Despite its economic growth, the poverty rate in Indonesia remains high (3). Indonesia continues to have a sizable debt and access to basic services such as health and education remains poor (4). The fall of the Soharto regime by no means marked the end of the era of corrupt government. Although the anti-corruption commission was established, corrupt practices continue to increase. Based on the international survey of the Transparency Institute (TI) based in Berlin, Germany, Indonesia scored 32 with being the most corrupt and the 100 the cleanest state. The survey was conducted on 176 countries around the world. On the corruption index, Indonesia rose from a ranking of 100 to 118 , which made Indonesia the most corrupt country in Asia; beating the Philippines (105), Thailand (88), China (80), Malaysia (54), Japan (17), and Singapore (5).

There are some scholars whom analyze Islam and development in Indonesia with Weber's thesis framework such as Koch, Leur, Castles, and Wertheim (5-7). Weber's observations are often used as an analytical paradigm of development, especially for developing countries. This paradigm taught that if developing countries want a successful economy, they must have a high work ethic that is manifested in the spirit of hard work and simple and frugal living like the Calvinists in Europe. In the other words, this paradigm teaches that the problems of development and underdevelopment is closely related to the issue of the work ethic. The better the work ethic that is manifested in a community's willingness to work hard and live frugally, the more likely they will succeed in developing a strong economy. Failure to develop a strong work ethic will lead to a failed economy.

Weber's works were further elaborated by Ernst Troeltsch in his book Protestanism and Progress: The Significance of Protestanism for the Rise of the Modern World in which Troeltsch emphasized that Weber had an important influence on the development and behavior of society and encouraged the economic modernization of European society. In his Tokugawa Religion, Robert N. Bellah applied Weberian theories on the study of the Japanese society to identify the relationship between religion and economic development (8).

The majority of Indonesians are Muslim and its laws and regulations in addition to the economic progress of the country largely depend on the Indonesian Muslims. In one side that country is abundance of resources, in the other side that resources can not be used to make people wealth. This paper reviews some articles which analyze role of Muslim to Islamic economy development in Indonesia. 


\section{RELIGION AND DEVELOPMENT}

According to Weber's observations of the Protestant Puritanism Calvinist sect, there's is a culture that assumes that hard work is a must for any man to attain spiritual well-being (9). They believe that hard work is a spiritual call to reach perfection in life. As a result of this encouragement, hard work has translated into an abundance of wealth. With hard work, the frugal and simple life of the Calvinists did not only facilitate a better life but also transformed them into strong self-employed individuals who constituted the backbone of the capitalist economic system.

To make a comprehensive study of the relationship between religion and social structures and dynamics, Weber conducted a thorough study of the major religions in the world, namely ancient Judaism, the religions of India, and the religions of China. Unfortunately, he did not have time to make a thorough study of Islam. However, when he attempted to form theories on religion and society, Weber considered Islam a radical universal religion of monotheism (10).

Rodinson and Turner critically examined the weaknesses of Weber's argument about the validity of his thesis on Islam and the relationship between religion and economic behavior (11). They said that Weber never study Islam deeply. Weber's assumption will be trapped in his wrong mindset.

Weber said that Islam, came from the simple theology with the task to make clear differences between religious revelation and paganism. In early Islamic theological debate, the main topic is about the most important teachings of God's grace. The privilege Islamic is that the validity of truth dogma is determined by consensus of the scholars (12).

Weber thought that Islam is the religion of soldiers. In the early-Islamic era, the warrior class clearly established a religious community. For the soldiers, the "war of religion" is to get the spoils, primarily in the form of land (13).

The Islamic Economic historian such as El-Ashker, AbdulFattah and Wilson (14); Ghazanfar (15); Nagaoka (16) replied that the result of land tax ('ushur, fai') is used for the benefit of the people in the form of infrastructure development. In addition, productive land leasing was the prevailing in feudal system. Instead in the Islamic system, it is not permitted. Since in Caliph Umar bin Khattab, If the owners of productive land could not manage it in the past three years, the state would confiscate the land was handed over to the other person who are able to manage it. With this regulation, throughout the 13th century the economic history of Islam never happen the process of impoverishment except in one or two cases of misconduct by agents of state personally.

In one side, It seem that Weber is not quite able to break away from its European ethnocentrism, so that he frequent misunderstanding the internal dynamics of those religions. In the other side, his theory has helped many social scientists to describe and explain the various social realities. In studies of Indonesia, the influence of Weber's thesis can be seen in the descriptions of sociologies and anthropological cases.
His thesis has contributed to liberate the history of Indonesia from the perspective of philology and change in history. Furthermore weber's theory has also been used to understand the relationship between behavior and economic development and spiritual awareness among the socialeconomic structure and doctrine believed. With Weber's framework, there was a book that linked the Indonesian economic growth retardation with mysticism in society(17).

DMG Koch, a Dutch socialist, was the first sociolog to analyze Islam in Indonesia with Weber's theory framework. After independence, his book about the history of the Indonesian nationalist movement became famous. He put in a Weber analysis outlines the emergence of the Islamic union among the traders in Surakarta, Java (5). Unfortunatey, he wrote it to the Dutch government report, the effect on the world of knowledge about Indonesia is almost non-existent. Schrieke reported to the government, about the "communist insurgency" in West Sumatra in 1927 (18). He also saw the possibility of an affinity between the rise of Islamic reform movements in the economic life premises Minangkabau people who engaged in the export economy. Changes in the structure and trends in the religious life destabilize joints and indigenous agrarian communities. Here, the word Schrieke, is the main factor of the famous rebellion. Schrieke's report was well received in the academic world, after the book was published in English in 1950.

Weber theory is not only evocative reconstruction of historical accuracy by experts, which are generally the philologist and archaeologist, but it also opened up new possibilities in understanding the dynamical history of Indonesia and Southeast Asia generally (6). Van Leur although accepted the hypothesis that Islam came to Indonesia through the trade route, but he argued that the development of Islam due to the "political situation and political motives" (17).

Trend of Islamization was getting more political motive with the arrival of the Christian West. Van Leur seems to proceed from the assumption that Islam is essentially a religion of warriors, whom as also referred to by Max Weber, once aware of the status of their group. Because Islam in Indonesia, apparently has not roled for the development because of economic mentality. The most influence of Islam is in the field of literature and the humanities course. He said that It did not have a direct relationship with the social and economic organization. Social distance between the learned (ulama) and the traders and hawkers are too far. The nature of knowledge is too "scholastic". Unfortunately, Leur's assumption is not correct, because he did not analyze precisely that Western imperialism impeded the role of Muslims in development.

In testing the validity of Weber's thesis, Alatas ensure that the Weber thesis suggests a causal relationship-one symptoms cause other symptoms-not just looking for a mutual affinity. He, therefore, argued Weber's thesis. Why fellow Muslims in the Malay and Indonesian had got differences in attitudes and 
economic behavior, he asked. While some ethnic groups showed a high sensitivity to economic activity, the others remain only a single object, though they are co-religionists.

In addition, Geertz took people who aware of cultural unity, as well as aware of the difference (variant) in understanding of religion, as in "Modjokuto" or status like in "Tabanan". Santri (Student in islamic boarding school) in "Modjokuto" and nobility in Tabanan is familiar in social community, both from the point of ethnic and geographical angle. If in the case of Tabanan, the economic activities of the nationality can be seen as an encouragement of social status, then in the case of "santri", Geertz have a look a parallelism with the proper functioning of the "Protestant ethic". Both of the nobility in Tabanan and santri in "Modjokuto" was undergoing reform. in the sense of Weber, Geertz saw elements of a close relationship between the religious life and entrepreneurship in iron craft entrepreneurs who are not the followers of reformist Islam (19). In other words the devout Islamic traditionalists find matching with dynamic entrepreneurship. "Spirit of capitalism" in term of the sense of industrious, thrifty and countably in those santri community. Unfortunately those spirits were not supported by good organizational skills (17).

There was a close relationship between the religious life and entrepreneurship in iron craft entrepreneurs who are not the followers of reformist Islam (19). In other words a dynamic entrepreneurship found compatibility with the devout Islamic traditionalists.

Siegel did pay more attention to personal attitudes in economic activity. While Geertz tried to capture the spiritual situation in coloring economic activities and then he tried to link it to economic activity. Both of them saw the weaknesses of organization as a major obstacle to the improvement of the economic capacity of students (santri) in Java and traders in Aceh. Based on this reason, Wertheim doubted the ability of students (santri) to increase their ability over bazaar traders.

Wertheim is more interested in the general economic climate rather than work ethic. He thought that the economic development of a country is more determined by the attitude of the bureaucracy. In another angle, it can be said Wertheim confirmed Weber theory that the bureaucracy will eventually surpass capitalism.

Government policies determine the economic policy of a State. Thus, the economic plan should be run by the developing countries. In Indonesia application, It is not only supported by political prejudice but also scientific observation (20).

\section{ROLE OF MUSLIM IN INDONESIA FOR ISLAMIC ECONOMY DEVELOPMENT}

According to the South Commission Report and Choudury, development is defined as a process of self-reliant growth, achieved through the participation of the people acting in their own interests as they see them, and under their own control. The first objective of development is to alleviate poverty, provide productive employment, and satisfy the basic needs of all the people, any surplus being fairly shared (21-23).

Development planning in Indonesia can be proposed by various parties, e.g. political parties, mass organizations, NGOs, and other community components. There are several Islamic parties that have clear platform of development. Here are platform or concept of economic development from some parties which have dominant members of Muslim in Indonesia.

The platform of economic development of Partai Keadilan Sejahtera (PKS) briefly include: 1) To encourage the creation of decent work for humanity to eradicate poverty and promote equitable distribution of income and welfare programs through empowerment of the poor and informal sector. 2) To build a strong national industry and highly competitive, quality-based human resources and adequate technological innovation capabilities in order to achieve national independence. 3) To achieve growth in high value-added economy to achieve sustainable development based on the integration between sectors and regions based development and potential regional outreach. 4) To restrict the actions of speculation, monopoly and economic crimes committed by the ruler of the capital and other economic resources to guarantee equality for all business actors for the realization of an egalitarian economy.

Although in some parts of the platform there is a tendency of overlapping, the concept offered the party relies on agriculture. The party wants to make the eradication of poverty by increasing human resources, mastery of technology, infrastructure development and bureaucratic reform. The concern is that all the partiesoffered takes time for implementation. "Human Capital" can not be done in the blink of an eye. There is still unknown what concrete steps to be taken in the short term while building long-term human resources.

The most interesting of those concept is the development sector which is a source of new growth. This concept requires human resources and technology. This offer is not seen clearly in the economic concept of the other parties. Although they are both the lack of a clear action plan, but PKS is more advanced in the discourse that is not enough to make use of existing natural resources but Indonesia should be more advanced and develop the natural resources into capital for new sources of growth. Though all contain the principles of Islam, its Islamic concept is not explicitly shown.

While the platform of Partai Persatuan Pembangunan (PPP) ix reinforce alignments the concepts and democratic economic system, the realization of economic justice, the state's control over the branches that dominate economic life of the people, and the maximization of the role of state-owned enterprises, and encourage increased national self-reliance (business unit family / individual, private enterprises, state enterprises and cooperatives). Similarity between the PPP platform with PKS is providing jobs, poverty alleviation for the realization of economic independence and Indonesia.

According to Faisal Baasir (member of board PPP), the concept of Islamic economics is an economic concept that starts from the failure of the concept of free market economy 
and the concept of a socialist economy. With a strong emphasis on ethical values which are derived from the Qur'an and hadith the Prophet Muhammad. Faisal believes islamic economic can be an alternative to overcome the weaknesses in the concept of the capitalist economy and a socialist economy concept. PPP argues that economic policy has clearly affirmed in the Constitution of 1945. Economic development aimed at realizing the prosperity of all people. On this basis, according to Faisal, the prevailing economic order in Indonesia should be cored populist economic concepts that should be able to give as well as take advantage of opportunities created equally and prevent inequality and injustice in society. For this reason the growth of economic institutions and Islamic finance need to be encouraged.

The Platform of development of the National Mandate Party (PAN) expressed by Dradjad H Wibowo, strongly support the concept that aims to improve the economic welfare of the community both in conventional and Islamic economic. Drajat believed that Islamic economic concept that has been implemented with the establishment of Islamic financial institutions, is a goo economic concept that can improve the welfare of the community by encouraging the pace of the real sector. But he also warned that the existing pluralism in Indonesia, may not impose Islamic economic as the only concept to apply in Indonesia. Drajad acknowledged that the implementation of Islamic finance in Indonesia is new. It is natural that its contribution to the national economy is still small. only one institution that supports the development of Islamic economics, namely Bank of Indonesia (central bank). Islamic economic development should start by improving the operational range of the existing Islamic financial institutions, including internal reform and not just focus on the desire to pass various legislation in support of Islamic financial institutions.

According to M Zubair, member of central committee of the Nation Awakening Party (PKB), recognizes there were differences of opinion in the internl party about Islamic economics. It was because of a lack of knowledge about the Islamic financial services. Now it emerges a common perception for PKB activists to promote the Islamic economic system to the public. Economic vision of this party concerns in small and medium enterprise sector through the ease of access to capital. Currently the bank has access to only the upper class. While SMEs have difficulties to reach due to the various requirements that complicate burdened. PKB also asked state budget directed to the SMEs sector and to delay foreign debt.xii

Crescent Star Party (PBB) has four programs in the field of Islamic economics. (1) To support the development of Islamic financial institutions that already exist. (2) To create Islamic Banking Act. (3) To establish an institution which take care of Islamic banking in Central Bank of Indonesia in deputy level. (4) to disseminate simultaneously the Islamic economy, both at the central level and at the level of his supportersxiii. Though almost all of these programs have been implemented, but why they are still as the party's program?

There is a nationalist party in Indonesia also supporting Islamic economics. Harry Azhar Aziz, the central committee of the Golkar Party said that the monetary sector indicators did improve, but it is not followed by the real sector indicators that unemployment is increasing. Islamic economic vision of this party is in the context of the development of the real sector by providing support for Sharia Rural Banks and BMT (islamic microfinance) that support the growth of SMEs. One thing that also highlighted the Golkar Party, Islamic economic institutions is not yet enough supporting the legal system in Indonesia. For example, the Islamic banking system is not only based on profit-sharing, but also the loss sharing. In the context of loss sharing, those who have had moral hazard which could be detrimental to the Shariah banking. He promised that his party will propose a better rule of law for Islamic banking. Besides, Golkar party argues that the failure of development in the previous New Order (which Golkar leaded) lies not in the failure of economic growth but rather on economic injustice. Therefore Golkar platform for today's highly stressed fairness, similar to the issues that brought by the Islamic economy.

It is not only political party that has a platform of development policy, but Islamic mass organizations (NGOs) also periodically meet to discuss various issues and to find alternative solutions for a better Indonesian in Islamic perspective. One of the proposals is as described below.

In Islamic Economics perspective, states only provide opportunities for economic actors to engage in the field of real sector economics or production (24), in the areas of agriculture, manufacturing, trade and pemissible services. Islam prohibits development in the non-real sectors economics such as derivatives capital market. Therefore, the developing economic in the non-real (financial sector) to violate the laws of Islam. In addition, the distribution of the economy circulates on the rich only (25). The implementation of forbidden in economic, such as riba nashi'ah, Fadl usury, gambling or speculation (maysir), gharar and so on, became the main base for economic growth in the non-real sectors (26).

There are several factors that can determine the success of the development, for example: natural resources, human resources, capital, technological advances, etc. (27). The most important factor, Based on Adam Smith, is capital. If a country wants to continue its economic growth, that country should be more focus on the accumulation of capital (28).

Capital accumulation in a country can be collected by people whom are fond of saving money in the bank If the people still low savings rate, capital will be a problem for economic development process (29). The easy and fast solution to overcome this problem is to seek external debt or attract foreign capital investment (30). Most of developing countries use this method to solve their capital economic development problem.

After years developing country with foreign debt and foreign capital investment, the lack of income between rich and poor people, the amount of foreign debt and its interest increase significantly (31). Indeed foreign debt and foreign capital investment is a trap made Indonesia become dependent on the West, both in technology and economics. 
The model of Development in Indonesia is prepared in reverse. The model of Development that was initiated from the upstream sector, and then move towards the downstream sector, namely the development of the agricultural sector first and then move towards the peak, which is the development of heavy industry (30).

The model of economic development for Islamic mass organization perspective is the beginning of the downstream sector, and then headed to the upstream sector. The stages of economic development must be begun from heavy industry to high technology mastery, then sought industrial development supporting, and self-reliance in agriculture (32).

When Indonesia began development of the agricultural sector, to achieve agricultural self-sufficiency required many supporting inputs such as: the superior grains, heavy equipments, farm equipments, fertilizer needs, pesticides, insecticides, herbicides, farmers need skills upgrading programs, etc (33).

Unfortunately, the developing country which uses reverse developing model, should import all farmers needing from developed countries (West). The farmers do not have enough money to do that, except the foreign debt which has been prepared by the Western countries to developing country, including Indonesia (34).

When Indonesia has succeeded in producing enough rice, Indonesia's foreign debt is getting increased. As a result, the state budget is more deficit to pay the mortgage debt plus interest, rather than to finance development. The way to finance their development is to open wide financial sector (liberalization of the financial sector), by giving freedom to open bank for private parties, capital markets, foreign exchange market (forex), the traffic flow of international capital and so on (30).

This effort did seem to give outstanding results in economic growth in Indonesia. Unfortunately, this is a shadow economic growth, not real one. Therefore, economic growth just ballooned in the non-real sectors. The facts show that the velocity of money in the real sector absorbs only 5\%, while the remaining $95 \%$ spinning in the non-real such as on the capital market trading, without any much impact to the real economy. The predictable result is that economic bubble (economic bubble) could explode at any time and it causes the economic crisis. That phenomenon has hit Indonesia in the year 1997/1998,. The economic crisis caused by non-real sectors based economic development is cyclic. It means the economic crisis will continue to appear periodically with the frequency decreasing. If the first period of crisis occurs every 20 years, later increased to 10 years, now it has reached 5 years (3).

To finance the development should be from independent state budget and should not use foreign debt and foreign capital investment (26). The independent state income should be from three sources. First, Individual ownership sectors such as: charity, donation, charity etc.. Second, common ownership sectors such as: large mines, the sources of petroleum, gas, coal major, etc. forestry sector. Third, State ownership sectors such as taxex, jizya, kharaj, ghanimah, fa'i, 'usyur etc..
The reliable Indonesian largest revenue source is a mining and energy sector, in condition that the common ownership of the sector managed by the state (1). State should ban individuals or private to manage unfair natural resources, especially by foreign private. The state's role was limited to manage, then the result should be returned to the people as public facilities, infrastructures, assurance of public health, education and security.

Ruslan Abdul Ghani explained that after world war II in 1939, Indonesia has three growth periods (35). There are state building period (1945-1959), nation character building period (1959-1969), and economic development period (1969current). Although the main discussion is in the third period, it will be discussed the other periods at a glance, because they have the interrelationship.

The concept of Islamic economics can be viewed as an alternative solution to deal with the weakness of the idea of Western ideas of liberal globalization and modernization. In the 1980s, Muslim leaders have systematic attention to the problems of poverty and inequality in the distribution. They believe that the ideals of the Islamic ethics and moral traditions should solve this problem. Especially after the Asian crisis in 1997, the country's dramatic economic problems the country after Suharto era (36).

Islam has the moral principles that clearly the purpose of economic justice and community. The most important Islamic finance is the prohibition of interest (riba) on loans and loans to prevent usury and economic exploitation. Financial products or services which similar to interest is forbidden (haram). In general, the Quran and the Hadith provide basic orientation on economic issues. Trade and entrepreneurship are acceptable and desirable if the prohibition of usury are respected. All activities related to economic issues should follow the ethical principles of Sharia (37).

In the mid-1980s, the Indonesian government, which sets the institutional and legal framework for Islamic business ethics, reacting to pressure from the Islamic movement and the influence of Islam. There were some important evidence in term of Islamic Economic development. The first Islamic Bank in Indonesia BMI (Bank Muamalat Indonesia) was established in 1991 with the help of the MUI (38). Another evidence is a new law on Islamic banking implemented in 1992 to facilitate the establishment of Islamic banking with the concept of profit-and-loss-sharing (Mudaraba) and joint venture (Musharaka), from 1999 onwards, those principles have applied to all Islamic financial transactions. In a third area of 1999, zakat regulation raised to the status of national development instruments. This step is based on the effort during the Soeharto era to expand and institutionalize zakat as a measure of poverty reduction (e.g. through BAZIS, quasistate agencies regulate the distribution of zakat). To fulfill the need of human resources in Islamic financial sectors, public and private Universities and colleges offer courses on Islam Islamic economics, finance, business ethics and commercial law. A few years later, Indonesia has regulation about charitable foundation (Endowments) that are used to maintain public facilities such as mosques, schools and hospitals. Unfortunately, the greatest both two socio-religious organization in Indonesia, NU and Muhammadiyah, differ in 
their views on Islamic economics, especially on the issue of usury. NU at a certain scale in order to tolerate the application of interest in term of "maslahah". While Muhammadiyah basically considers interest as illegal. Because of that decision, Muhammadiyah encourage and facilitate the establishment of Islamic financial institutions and the economy (39).

In the reality of economic policy and development in Indonesia, sharia-based financial institutions have so far played an important role but not so significant. In the year of 2000 there were only eight Islamic banks and 80 islamic rural banks (BPRS). However, the rapid growth in the number of local sharia-based Islamic savings and credit cooperatives (BMT; Bait Maal Wat Tamwil) observed in the 90s. The BMT nearly 2,500 registered in Indonesia in the year 2000 (40). Furthermore, in the same year, about 1,400 small savings and credit institutions registered in Indonesia, which is attached to the mosques or schools, known as Kopontren (Cooperative in Islamic boarding school). Since the 1990s, NU has sponsored local microfinance institutions and micro-credit programs explicitly with Muslim customers (41).

Although almost 23 years of experience with the concept of Islamic banking and finance, there is a lack of practitioners and scholars who has expert in both economics science and Islamic studies as well. Besides, there are the lack of regulations, particularly in the microfinance sector. Another problem is the lack of trained personnel and awareness of efficient working techniques and formal rules. Islamic microfinance institutions facilitate financial services for micro-small medium enterprises. This institution uses zakah and other charity funding for poor people (42).

Indonesia is called as the largest democracy in the Muslim world. However at this time there is a tendency majority Indonesian people want Islamic Sharia implementation in development. A recent survey released by the Pew Research Center (May 2013) revealed that 72 percent of Indonesian society supports Islamic Sharia as the "official state law". That research center conducted a survey in 39 countries and interviewed 38,000 people. That institution found that most moslem in the world want to Islam not only applied to their personal lives, but also on the social and political relations .

This current situation is very crucial and determine the future development in Indonesia. When in one side people want a fundamental change of policy makers, in the other side some rulers are still running the corrupt practices, then one day there will be a great clash between the people and the rulers. The success key of change is on the hand of the military.

\section{CONCLUDING REMARK}

All Muslim elements for instance political party, mass organization, scholars, and scientist have signficant contributions for developing Islamic Economy in Indonesia.

Discussion on the best model of development in Indonesia is still in progress among the scholars, scientist, political party and mass organizations. There are three school of thought in term of development concept. First, the concept of development that is based on classical and neoclassical economists. Second, the concept of development based on fully Islamic system. Third, both with adjustable compromising situations and conditions in Indonesia.

Although some surveys showed that the majority of the Indonesian requires the implementation of Islamic law, all component such as Islamic scholars, political party, mass organization etc should socialize and educate people both muslim and non-muslim including general in military with an excellent Islamic concept of development to be a better Indonesia. Thus the development that they want will occur running smoothly and full consciousness.

\section{ACKNOWLEDGMENT}

I would like to express my sincere gratitude to Prof. Dr. Mohamed Aslam Haneef for his guidance. Without his valuable-assistance, this article would not be done.

\section{REFERENCES}

[1] Suryantoro S, Manaf MH. The Indonesian Energy And Mineral Resources Development And Its Environmental Management To Support Sutainable National Economic Development. Foreign Direct Investment and the Environment. 2002. p. 7-8.

[2] McKinsey. McKinsey on Finance. Corp Financ [Internet]. 2006;32(23):5-16. Available from: http://www.performancesconsulting.com/bibliotheque/veille/strategie16 1.pdf

[3] Dhanani S, Islam I. Poverty , Vulnerability and Social Protection in a Period of Crisis : The Case of Indonesia. 2002;30(7):1211-31.

[4] Asia Foundation. Organisasi Islam dan Pembangunan di Indonesia. Jakarta; 2008.

[5] Koch DMG. Om de Vrijheid. Djakarta: Jajasan Pembangunan; 1950.

[6] Leur JC Van. Indonesian Trade and Society. The Hague/ Bandung: W. Van Hoeve Ltd; 1955.

[7] Castles. Religion, Politics and Economic Behavior: the Kudus Cigarette Industry. New haven: Yale University Southeast Asian Studies; 1957.

[8] Ichsan MAB. Islam dan pembangunan ekonomi. Atjeh Post [Internet]. Aceh; $2013 \quad$ Feb 17; Available from: http://atjehpost.com/saleum_read/2013/02/17/40252/77/3/Islam-danpembangunan-ekonomi

[9] Weber MT by TP. The Protestant Ethic and the Spirit of Capitalism. London: Routledge; 2005.

[10] Max Weber Translated by Ephraim Fischoff. The Sociology of Religion. Boston: Beacon Press; 1964.

[11] Turner BS. Revisiting Weber and Islam. Br J Sociol [Internet]. 2010 Jan [cited 2013 Apr 10];61 Suppl 1:161-6. Available from: http://www.ncbi.nlm.nih.gov/pubmed/20092489

[12] Rahman F. Islam. New York: Anchor Book; 1968. 264-267 p.

[13] Reinhard Bendix. Max Weber: an Intelectual Portrait. New York: Double Day, Anchor Book; 1962.

[14] El-Ashker, Ahmed Abdel-Fattah \& Wilson R. Islamic Economics: A Short History. Leiden: The Netherlands Koninklijke Brill Academia Publisher; 2006. 450 p.

[15] Ghazanfar SM. Medieval Islamic economic thought: filling the "Great Gap" in European. London, UK: Routledge Curzon; 2003.

[16] Nagaoka S. Critical Overview of the History of Islamic Economics: Formation, Transformation, and New Horizons. Departemental bulletin paper of Asian and African Area Studies. Kyoto, Japan; 2012 Nov. Report No.: 11.

[17] Abdullah T. Agama, Etos Kerja dan Perkembangan Ekonomi. Jakarta: LP3ES; 1979. 
[18] Dove MR, Kammen DM. Vernacular Models of Development: An Analysis of Indonesia Under the " New Order . World Dev. 2001;29(4):619-39.

[19] Kuntowidjojo. Notes on the Community of Batur Indonesia. 12 Oktober. $1971 ; 47-56$.

[20] Abdullah T. Islam di Indonesia. Jakarta: Tintamas; 1974.

[21] Fatah FA, Othman N, Abdullah S. Economic Growth, Political Freedom and Human Development: China , Indonesia and Malaysia. 2012;3(1):291-9.

[22] Choudhury MA. Islamic Perspective of Socioeconomic Development. J Islam Econ Bank Financ. 2009;6(3).

[23] Commission S. The Challenge to the South. Oxford, English: Oxford University Press; 1990.

[24] Eljurnal. Pembangunan EKonomi dalam Sistem Islam; Konsep dan Prioritas [Internet]. Intizar, IAIN Raden Fatah-Palembang. Palembang; 2012. Available from: http://eljurnal.wordpress.com/2012/04/24/pembangunan-ekonomidalam-sistem-islam-konsep-dan-prioritas/\#more-128

[25] Ghofur R. Distribution Policy on Islamic Economics. Islam J Islam Stud [Internet]. 2012; Available from: http://ssrn.com/abstract=2189964

[26] Harwood JB, Wali S. The Economic Growth Imperative within Capitalism and the Islamic Viewpoint. 2013;(February).

[27] Santoso D. Kewirausahaan: Modul pembelajaran. Jakarta; 2013.

[28] Deliarnov. Perkembangan Pemikiran Ekonomi. Revision. Jakarta: RajaGrafindo Persada; 1997.

[29] Ambari LW. The Sharia Practices for Establishing Sustainable Mining Industry. Sharia Economics Conference. 2013. p. 145-53.

[30] Triono DC. Capitalism Failed: Islamic Macroeconomic and Public Policy Turning Point. 2013;(February):8432.
[31] Kartikasari E. Membangun Indonesia Tanpa Pajak dan Utang. Abdurrahman H, editor. Al-Azhar Press; 2010. 163 p.

[32] Al-Maliki A. As-Siyasah Al-Iqtishadiyah Al-Mutsla. Bangil: Al-Izzah; 2001.

[33] Mansur A. Is Indonesia Undergoing a Process of De-Industrialization? The Hague, The Netherlands; 2008.

[34] Asmuni. Konsep Pembangunan Ekonomi Islam. Al-Mawarid. 2003;X:128-51

[35] Chirzin MH. The Development of Civil Society in Indonesia and the Role of Voluntary Organizations. Am J Islam Soc Sci. 2000;17(1).

[36] Hadiz VR. Indonesian Political Islam :Capitalist Development and the Legacies of the Cold War. J Curr Southeast Asian Aff. 2011;30(1):3-38.

[37] Cattelan V. Shari'ah Economics as Autonomous Paradigm : Theoretical Approach and Operative Outcomes. Sharia Economics Conference. Hannover: SEC, Hannover, Germany; 2013.

[38] Al S, Choiruzzad B. The Central Bank in the Development of Islamic Economy Project in Indonesia: Role, Motivations and Moderating Effect. 立命館国際研究. 2011;25(2):87-110.

[39] Teik KB, Hadiz VR. Critical connections: Islamic politics and political economy in Indonesia and Malaysia. 2010;(239).

[40] Nasution AC. A Framework To Analyse The Efficiency Of Baitul Maal wa Tamwil ( BMT ) As Islamic Microfinance Institutions in Indonesia. 2013;(February):81-6.

[41] Kasri RA. The Determinants of Islamic Banking Growth in Indonesia. J Islam Econ Bank Financ. 2011;6(2):41-64.

[42] Ghofur RA. The Concept of Distribution in the Islamic Economic System. State Islamic University Sunan Kalijaga Jogjakarta; 2011. 